\title{
TREVPAR's Rates Development, Average Income and OCC of Brazilian's Resorts During 2014/2015 Two-Year-Time
}

\author{
Antonio Carlos Bonfato ${ }^{1}$, Barbara Hansing ${ }^{2}$ \& Erica Casarini Silva ${ }^{1}$ \\ ${ }^{1}$ Centro Universitário Senac Águas de São Pedro - CAP, São Paulo, Brasil \\ ${ }^{2}$ Centro Universitário Senac Santo Amaro - CAS, São Paulo, Brasil \\ Correspondence: Antonio Carlos Bonfato, Professor, Centro Universitário Senac Águas de São Pedro, CEP \\ 13525-000, Brasil. Tel: 55-19-3482-7012. E-mail: abonfato@sp.senac.br
}

Received: September 13, 2017

Accepted: September 19, 2017

Online Published: September 20, 2017

doi:10.5539/jgg.v9n3p59

URL: http://dx.doi.org/10.5539/jgg.v9n3p59

\begin{abstract}
This article talks about the sales performance and income generation of Brazilian resorts based in enterprises associated with the Associação Brasileira de Resorts-ABR (Brazilian Association of Resorts -BAR) during 2014-2015. The article purpose understands how much the circumstantial factors interfere in rates generation in the hotel industry. The sales performance was measured by the occupancy rates related to the income through the TREVPAR's average income meters. These resorts were analyzed, first, in a general group of performance and, later, were segmented and analyzed into subgroups according to their geographical location - country side or the beach - and the daily rate - all-inclusive or other kind of rates (half board, etc). After rates obtained, it was concluded that the circumstantial and sector factors has strong influence in the resorts income. In addition to the overall performance of sales indices, could be noted that when put into subgroups, the resorts had different performances along the tow-year-period.
\end{abstract}

Keywords: resorts, hospitality, performance

\section{Introduction}

The article aims to study the means of lodging called resorts. The objective was to measure the level of affectation that macro and microeconomic factors exert in the performance of sales in these enterprises, in the biennium of 2014/2015. Over the years, Brazilian resorts have had a significant increase in participation and importance in the context of the national tourism trade. In an interview with the then president of the Brazilian Association of Resorts, held in 2014, it was possible to observe that until the end of the 1990s, resorts were characterized as independent enterprises, where family management predominated throughout the decades of 2000 and 2010, the sector recorded large investments, where most of the values came from traditional international resorts, such as the Fiesta, Iberostar and Vila Galé groups. The lack of data on the sector and - in particular - in Brazil, has always been a factor that made it difficult to interpret market behavior. It is still recent the adoption of informative and reports that allow the generation of a more precise behavioral scenario.

The sampling universe for this study was composed of the enterprises associated with the main representative entity of the area in the country: The Brazilian Association of Resorts - entity officially recognized by the Brazil's Ministry of Tourism, official representative of the sector in the country. It is also the only association focused on the resort sector, at the national level. The data collection used in this article occurred between the years 2014 and 2016, being collected directly in the BAR (Brazilian Association of Resorts) database. The members deposited the necessary information during the period of 24 months in a data base, allowing the recognition of the data. Although not the main objective of the study, indirectly, the survey also measured the impact that the Brazilian economic crisis generated on the revenues and sales of Brazilian resorts, as well as analyzed the impact of the mega-event of the 2014 FIFA World Cup on the sector. The indexes that served as measurement parameters were the occupancy rate; the average rate. The average rate is the division between the total revenue of the resorts by the number of UHs sold in a given period. The term "average rate" is used in all-inclusive resorts that do not separate the lodging income from the other sectors, as in the the average daily rate) and TRevPAR (the term TRevPAR is adopted instead of RevPar for the same reason of the average revenue. The TRevPAR represents the division of total revenue by the number of UHs made available for sale in a given period. 


\section{Method}

In the studies classification, the research is characterized as applied (Santella, 2006). Regarding the method, it is a descriptive research (Gil, 2001) where, for three years, between 2013 and 2015, the data were obtained from the resorts affiliated to the Brazilian Association of Resorts - BRA. During this period, resort managers deposited monthly the data that provided the basis for the issues here raised to be properly interpreted. The final results were systematized and analyzed. The data obtained were then put in analogy between the years, in order to obtain an indicator that showed percentages of positive or negative growth. This is a "correlational research": when the researcher follows, in relation to two or more variables, the joint fluctuation of the data (Costa, 2001: 50 ). The study initially sought secondary sources (Gil, 2008), analyzing literary works by authors such as Goeldner (2002), Mill (2003), Guijarro (2003) Weygandt (2005).

Market reports were prepared by government institutions, class representatives and specialized consultants, which dealt with the performance of hotel organizations in Brazil, such as BSH - Brasil Holding Service (BSH, 2011), Hotel Invest Canteras \& Associates, 2011) and Jones Lang LaSalle (JLL, 2013) and several editions of Resorts Brazil in Perspective - RBIP report, between 2013 and 2015. In the procedures adopted, the descriptive method (Laukatos, 2001;) was supported by quantitative information (Schlüter, 2003; Dencker, 2003 \& Santella, 2006, Gil, 2008) and qualitative data

The second moment of the research, after establishing the theoretical reference, was based on the data collection with the primary sources, resorting to the database created for the research, in conjunction with the Brazilian Association of Resorts - BRA. The instructions for sending the information were passed to the members in the General Assemblies of the entity, during the end of 2012 and beginning of 2013. In this sense the bases of the primary sources were.

i. Personal interviews with directors of the Brazilian Association of Resorts, between 2013 and 2014, represented by the executive director, Ricardo Domingues e;

ii. Data of occupancy rate, average revenue and TRevPAR, deposited with monthly constancy by members of ABR and also collected with monthly constancy.

The third phase was the creation of spreadsheets that were fed in a way to generate the variables that resulted in the final data of each index during the analyzed period. The next step was to transform the relevant data, drawn up in spreadsheets, into the graphics model, in order to facilitate the visual interpretation of the obtained data. The description of the analysis of the graphics and tables originated the texts that support the questions raised, in order to generate a conclusion of the present study.

The universe of resorts represents one of the most significant areas in the context of the lodging facilities, whether by the different and varied service offerings, or by the opportunities of financial returns and considerable mounts. However, in the field of academic studies and the offer of literary works, it does not have the same dynamics of production focused on urban or business hotels. Its almost unique characteristics were exposed by Robert Mill (2003):

'Resorts are actually a combination of three elements: recreational attractions to attract guests; lodging and food and beverage services to be offered to people who are far from their homes; and activities to occupy guests during their stay. (Mill, 2003: 11).

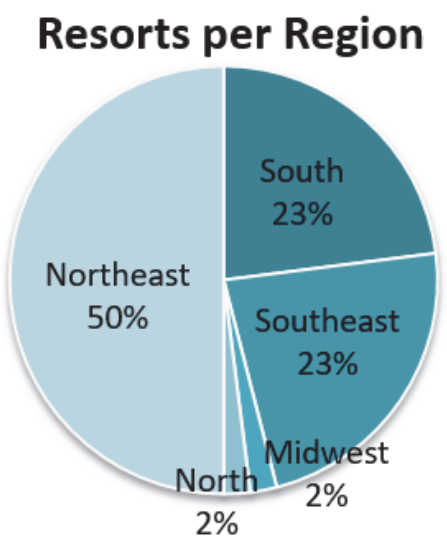

Figure 1. Resorts by Brazilian regions

Source: ABR - Brazilian Association of Resorts. 
The Brazilian Association of Resorts - BRA, in its electronic website defines the resorts as:

High-standard hotel developments in facilities and services, heavily aimed towards leisure in an area of great natural conviviality, in which the guest does not have to depart to meet their comfort, food, leisure and entertainment needs (ABR, 2014).

For the preparation of this study, we analyzed only the resorts affiliated to the Brazilian Association of Resorts BRA. The association has 49 associated establishments, distributed around Brazil, showing in figure 1. It is verified that the Northeast region has the largest number of resorts in the country, owning $50 \%$ of the affiliated resorts.

\section{Results}

\subsection{Brazilian Economic Context}

According to the Organization for Economic Cooperation and Development (2016), the global economy of 2015 closed at 3.4\%, and remained unstable throughout the year. According to international consultants in the area, China has slowed its pace of growth in recent years and has strongly impacted the economy of emerging countries such as Brazil, which are heavily dependent on commodity exports.

In Brazil, the economy suffered economic recession and, got worse by the unfavorable political environment, the Brazilian economic performance was the lowest in recent years. This scenario has generated reflexes in the domestic demand of consumers, and also loss of confidence from the national businessmen. "The final estimate is that 2015 has generated an economic downturn of up 4.5\% negative, according to the website of the specialized consultancy Trading Economics, which leaves the country below the growth of developed countries Euro Zone and USA, which grew by $1.2 \%$ and $2.1 \%$, respectively - and the main Latin American economies, such as Mexico, which recorded growth of 2.5\% in 2015 "(BAR, 2016: 3).

Figure 2 shows the performance of the Brazilian economy in relation to the most significant economies of the globe.

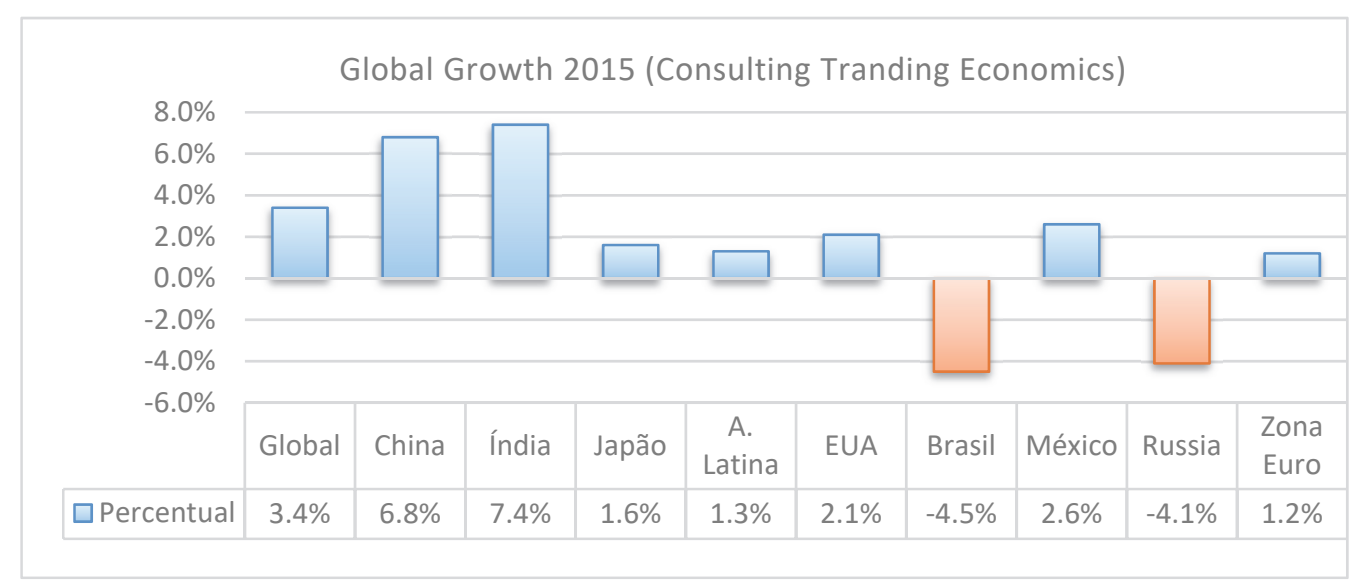

Figure 2. Global Growth in the Year 2015

Source: prepared by the authors based on data from Trading Economics.

\subsection{Tourism Context and Historical Performance of Resorts}

Tourism activity showed growth in 2014, but reversed the trend in the following year. According the Ministry of Tourism, international flights increased by $30.7 \%$ in 2014 , compared to the previous year, most part because FIFA's mega-event World Cup. The year 2015 oscillated between stagnation and low increase, as seen in the $0.7 \%$ increase in international landings, reaching 10,538,012 passengers.

In this process, the resorts sector also suffered the consequences. Referring to the BRA database, a growth market in 2014, but stagnated in 2015, was observed, so that the project managers applied sales policies aimed at customer maintenance and loyalty. Economic stagnation showed the first results from the second half of 2014 and the numbers generated have been reflected since then until the end of this research, in December 2015.

With the growth of the hotel market in Brazil, some organizations aimed at the sector begin to emerge in order to consolidate their area, as well as generate statistics and data regarding the lodging industry. More specifically, 
the Brazilian Association of Resorts - BRA was created to collect information exclusively from Brazilian resorts, helping resorts daily management, through the generation of data. Therefore, the sector begins to take a more professional form, seeking for help maintaining a historical database that can assist managers in the decision-making process. This database started to contribute to the market by generating sectoral sales performance information such as occupancy rates, average revenue and TRevPAR of the segment.

\subsection{Brief Description of Information Generation in the Brazilian Resorts Sector}

The national hotel activity has undergone a significant historical evolution in the last decades, coming from an almost absolute predominance of hotels operated independently, for a significant increase in the participation of the management made by national and international hotel chains. Authors such as Boeger (2005); Bonfato (2006), Prosérpio (2007) and Rosa (2008) discussed the dynamics of this process. In 2015, the networks administered $33.8 \%$ of the UHs offered daily in the country (JLL, 2016, 7). In the universe of Brazilian resorts, the process acquired the same nuances. Family-run businesses market share were giving up in favor of international resorts managements such as Iberostar and Fiesta, Spanish groups and Club Med (French origin). The professionalization and growth of the resort sector continued in concomitance with the country's own economic growth. This was the scenario between the beginning of the decade of 2000 and the end of that decade, according to the president of BRA in 2014. The report called Resorts in Brazil 2014, BSH - Brasil Service Holding (BSH, 2014 , 9) pointed out the existence of 119 means of lodging that could be classified as resorts. The offer of housing units rose 81.5\% in the four-year period, between 2010 and 2014 (BSH, 2014: 9). This fact led to the increased competition of the enterprises.

According to this fact, there was an increase in the level of demand from the national consumer who - with the improvement of purchasing power could travel more abroad - began to establish qualitative comparatives with resorts offered in other destinations. These factors pointed the need to improve the quality parameters of resorts that were in force until then. The process converged to a wider and more diversified services offer, a requalification of existing spaces and the construction of new resorts with a higher level of service. In this scenario, the improvement of management processes was almost natural (Bonfato, 2006). However, the generation of newsletter and specific reports for the resort sector was still in early stages. Needs were being suppressed as far as hotels, but little production for the resort sector.

The first reports that looked specifically at the national resort market date id from early 2010. Although late, these studies were important in providing the first market analysis tools for resort managers to use. The main problem was the lack of the periodicity of these analyzes, since they were sporadic reports and sometimes as little sampling. From that time, pioneering reports such as the "Investment Report in Brazil: hotels and resorts 2008", published by Brasil Holding Service Internacional (BSH, 2008). The consultancy issued a new report in 2011 and then in 2014. Jones Lang LaSalle - JLL Consulting has edited the "Resorts in Numbers" report for four editions also during this period.

In order to overcome this deficiency and generate data with a more constant temporality, in 2012 BRA signed a cooperation agreement with a traditional teaching and research institution in the area of hospitality: SENAC University Center, Higher Education Institution, with headquarters in São Paulo / SP. This agreement triggered the edition of the report "Resorts Brasil in Perspective - RBIP". Over time, the report was being analyzed, leaving only a few general indicators of performance, such as occupancy rates, average daily rates and RevPar, for the segmentation of the analysis in distinct resorts subgroups and seasonal behavior. Afterwards, the competition was analyzed and the concepts of Average Revenue and TRevPAR

\section{Discussion}

In macroeconomic terms, the year of 2014 was marked by the slight recovery of important economies of the globe, among them the resumption of the US economy (BRA, 2015: 3). On the other hand, China has cooled its growth pace, presenting figures - still significant - below the performance of previous years. As Brazil has its economy strongly tied to the sale of commodities to the Chinese market, this behavior affected the overall performance of the national economy, notably from the second half of 2014. The country ended the year with insignificant growth of the order of $0.1 \%$, according to the Portuguese BBC. In this context, the country's figures reflected the effects of the stagnant economy, even with the mega-event of the 2014 FIFA World Cup.

Regards to the aforementioned mega-event, the demand generated from foreign tourists was increased. The team's delegations participating in the tournament also contributed to this quantitative increase. According to the Ministry of Tourism such segments accounted for $58.5 \%$ of foreign leisure tourists in the year.

However, the figures were not repeated in the second phase of the mega event and the income generated by the 
resort market shows such a decline. In 2015, Brazil continued to suffer from the deceleration of Chinese economy growth rate. Adding to this were questions that triggered a growing process of political instability culminating the impeachment of former President Dilma Rousseff - and criminal investigation for corruption involving a wide range of politicians and businessmen from some of the largest organizations in the country (RBEP , 2015: 3). The result of this scenario was the negative growth of the Brazilian economy of $-4.5 \%$. Following this behavior, the revenues generated by the lodging and food services registered a decrease of $-5.5 \%$, according to IBGE (2016). The end of the year was particularly worrisome for this sector, especially in November 2015, which recorded a drop of $-7.2 \%$ in revenue generation. In this sense, the country's strong economic crisis was reflected in the activities of tourism companies. Following are the main findings regarding the specific performance of the resort area. It will also seek to establish a parallel between the performance of the sector itself and the behavior of the economy, in order to understand the behavior of the resorts within a larger economic context.

\subsection{Analysis of Overall Results}

The results were obtained through the treatment of the data deposited by the affiliated enterprises to the Brazilian Association of Resorts - BRA, during the survey period, from January 2014 to December 2015. In addition to the primary sources, the various editions of the Brazilian Resorts in Perspective reports served as secondary sources. Initially the data were analyzed globally, including all affiliated ventures. In a second moment, the ventures were divided into second subgroups:

i) its geographic location - countryside and beach;

ii) type of daily rate: all inclusive and other types of daily rates.

In the second moment, the assumed hypothesis is that as subdivided into groups, resorts tend to present differentiated results over a year. Indices that demonstrate the performance of the sales process were used as indicators, namely:

i) monthly and annual occupancy rate;

ii) monthly and annual average income and;

iii) monthly and annual TRevPAR.

The results are shown below.

\subsubsection{Occupancy Rate}

The employment rate at Brazilian resorts grew steadily from 2009 to 2014. The average annual growth rate was $5.9 \%$ per year. However, this evolution of sales volume was interrupted in 2015 , decrease of $-2.69 \%$, in relation to the same period of the previous year. Thus, the average annual growth - 2009-2015 period - fell to $4.7 \%$ per year. Figure 3 shows the historical evolution of the occupation rate in the years from 2009 to 2015 and their respective variations.

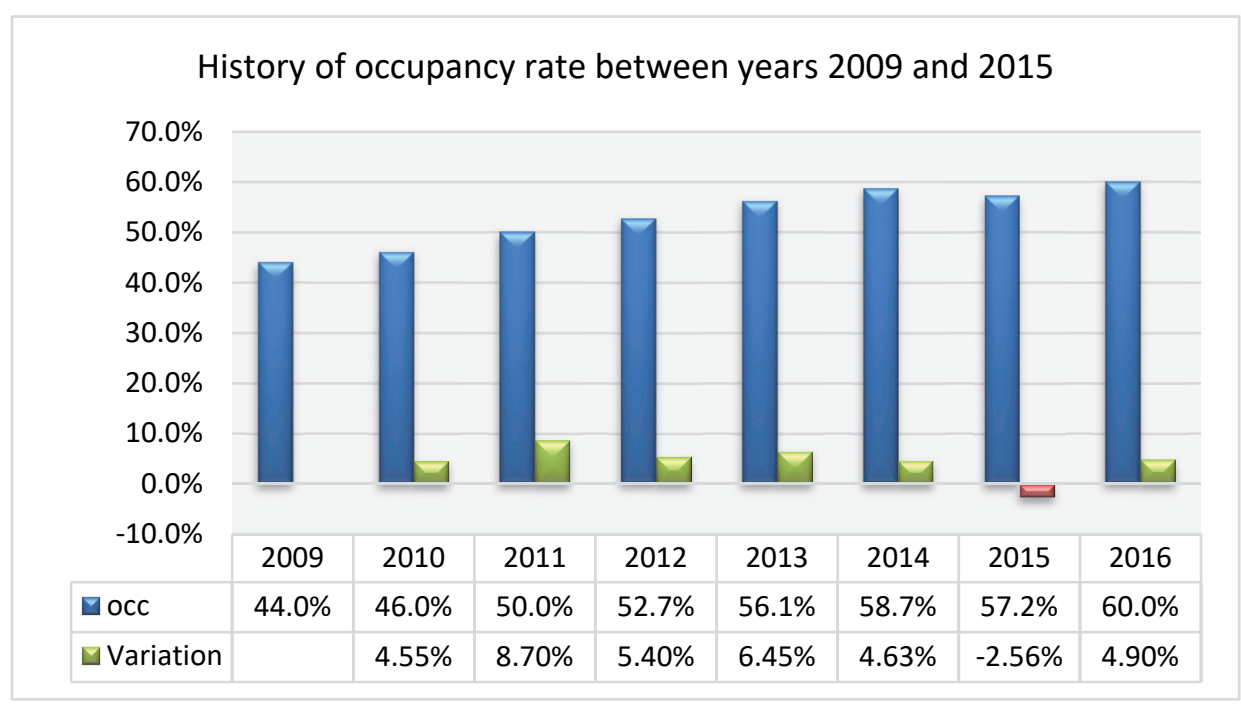

Figure 3. History of occupancy rate between years 2019 and 2015

Source: Prepared by the authors. 
Besides the macroeconomic facts, the mega sporting event, the FIFA World Cup, exerted influence in this index. What was noticed was the first half extremely favorable to the hospitality industry in 2014, which demonstrated a good occupancy rate for many Brazilian resorts, until June / 14. The occupation rate in the first half of 2014 was $7.2 \%$ higher than in 2013. On the other hand, the second half showed numbers that pointed in another direction, starting in July 2014. By establishing a parallel between this information and the scenario of tourism demand, the data generated point to some evidence: the first half was strongly influenced by the behavior of corporate demand, which advanced its events before the FIFA World Cup and held the facilities of the resorts significantly. In addition, the fact that in June the resorts were occupied both by the delegations and tourists who are fans of their teams. As the initial schedule of the games were pre-defined, it was possible to make reservations in advance and more linear planning. In the second half of the year, there was the expectation of the managers that the ventures showed a significant increase in occupancy, based on the so-called "comet syrup" effect, ie, the influx of foreigners would be greater due to the country's increased visibility, of the mega-event according to the president of BRA in 2014. In fact, the fact did not materialize, as shown by the indices collected in the present study, where the negative indices of the second half of 2014 are evidenced, as shown in graphs 4 and 5. Even with the weak performance of this semester, the annual index still showed a growth of $5.95 \%$, compared to 2013.

In contrast, the year 2015 pointed in the opposite direction with regard to the occupation rate: $-2.69 \%$ was the annual variation in relation to the previous year. This drop also maintains a direct relationship with the economic slowdown of the country. Thus, such a decline was already expected. In fact, the entire national tourism trade had undergone the same process. The resorts that had the demand for corporate events with a large historical participation in their market mix were the ones that felt the most effects: the segment was presenting increasing percentage of participation in the universe of segments that flock to the resorts. On the other hand, the demand made by national leisure tourists increased, due to the fact that the loss of purchasing power of the national currency, the real, have made travel abroad less attractive. The resorts located on the beach and that operated in the all inclusive scheme were the most benefited by this economic factor, as can be observed in the analysis by subcategories. Figure 4 shows the monthly performance of this item during the two years analyzed.

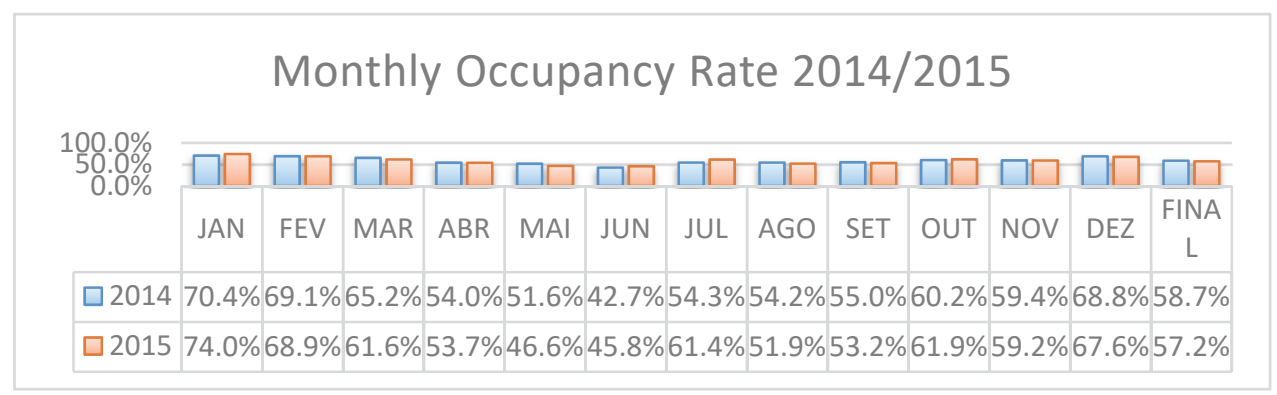

Figure 4. Monthly occupancy rate between 2014 and 2015

Source: Prepared by the authors.

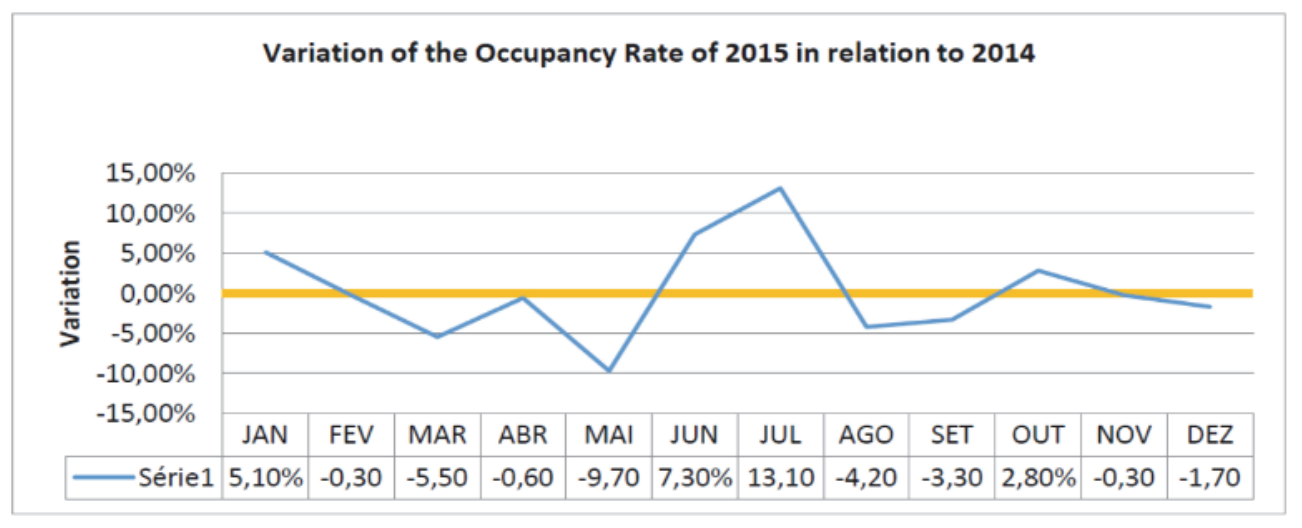

Figure 5. variation of the monthly occupancy rate between 2014 and 2015

Source: Prepared by the authors.

Figure 5 shows the variation in the occupation rate of the resorts, in a comparison between the previous year, 2014. 
The high peak of the year occurred in July, characterized by the demand for leisure, in high season due to school recess. These figures point to a continuation of the downward trend in the participation of corporate events during the months in which these activities intensify, that is, from March to May and September and October. On the other hand, they show the recovery of July / 15, mainly due to the high frequency of the projects, the domestic demand for leisure, which had repressed the search for international destinations, which became more expensive, driven by the rise of the dollar.

\subsubsection{Average Revenue}

In relation to 2014, the index increased slightly compared to the previous year: growth of $1.6 \%$, with average revenue rising from US \$ 181.27 in 2013 to US \$ 184.16 in 2014 Figure 6 shows the values.

There was a better performance in April, May and June 2014, reaching a peak of $40.1 \%$ in the last month - a direct consequence of the mega-event FIFA World Cup, with optimization of sales this month. When analyzed with annual temporality, the year 2014 showed great oscillations, showing satisfactory results in the first quarter, mainly in April and June (ABR, 2015: 18). In contrast to the good performance of unit revenues in the first half of the year, in the second half of the year many Brazilian families did not travel on July holidays, due to the expectation that the daily rates would be excessively high, due to the possible demand from foreign tourists, still reminiscent of the World Cup FIFA. After the analysis and treatment of the data, it was verified that this hypothesis did not take place, as shown in figure 6, where the month of July showed a stable behavior.

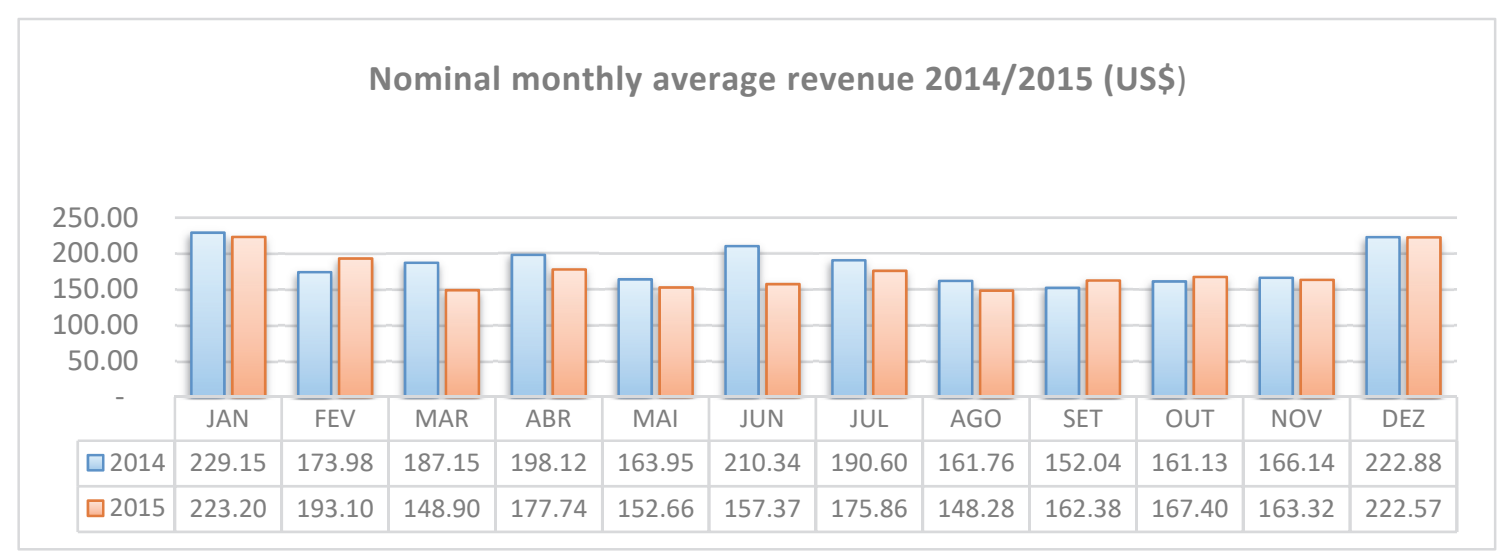

Figure 6. Nominal average monthly revenue between 2014 and 2015

Source: Prepared by the authors.

In summary, 2014, as a whole, still showed improvements compared to the previous year, but the following year showed, more acutely, the signs of the economic crisis, generating a decrease of $-5.39 \%$ in relation to nominal average revenue. Nominal average revenue shrank to $\$ 174.23$ in 2015 . Average revenue figures represent a drop in sales quality, with revenue management policies resulting in less significant amounts. However, it can be affirmed that the fall is due more to the macro-environmental conditions of the Brazilian economy than a loss of the effectiveness of the cited tool use. Pointing to such a statement, it should be noted that the fall in unit revenue was accompanied by the general fall in travel expenses in the country. The majority of the months of 2015 generated lower unit revenue in relation to the previous year, as can be observed in Figure 7.

Exceptions were the months of February, September and October of 2015, when there was an effective increase in nominal average revenue. It should be noted that nominal average revenues presented performance indices lower than the occupancy rate. Therefore, the true performance dimension must be observed when analyzing the index that shows the performance as a whole, either by the volume of sales or by the quality of sales: the TRevPAR generated by the years analyzed, as shown below. 


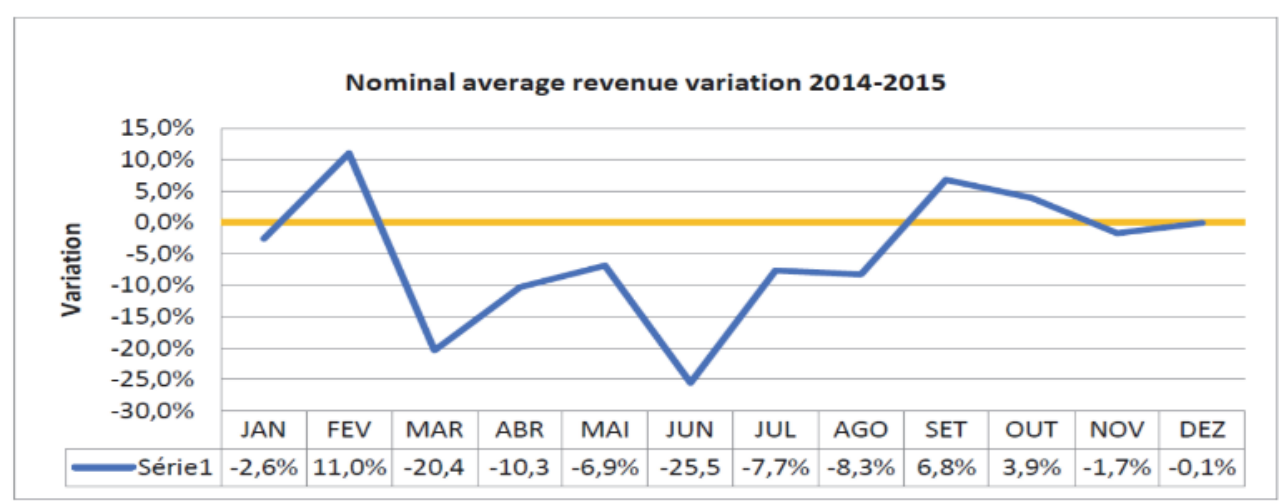

Figure 7. Average nominal monthly revenue variation between the years 2014 and 2015

Source: Prepared by the authors.

\subsubsection{TRevPAR}

In order to verify the true size of the sales behavior of the Brazilian resorts and to establish the analysis of the results on a more complete basis, the data were treated in such a way as to generate the TRevPAR generated by the associates during the analyzed period. By crossing the average revenue with the occupation rate, a value is obtained that combines quantitative data with qualitative data. Thus, after being systematized, it was found that the TRevPAR of Brazilian resorts fluctuated, during the years analyzed, $6.4 \%$ in the year 2014, compared to 2013. From US \$ 101.69 in 2013, TRevPAR rose to R \$ 108.18 in 2014. Thus, TRevPAR shows that the gains made in the first half of 2014, during which the FIFA World Cup was held, were somewhat higher than the losses of the second half of that year, when the first signs of the economic crisis came.

The year 2015 reflected the crisis scenario. The TRevPAR, of US \$ 99.60, was $-7.93 \%$ lower than in 2014 . The declines in both the occupancy rate and the average revenues reflected the purchasing behavior of demand during almost the entire year. In this case, with domestic demand reaching its peak of indebtedness (COPOM, 2015: 2), this segment was unable to sustain or restore the abrupt loss of other segments, such as corporate events, as an example. The steeper drop in average revenue affected the weaker fall in the occupancy rate. This behavior allows generating analysis information of fundamental importance, to be exposed in the final considerations. Figure 8 depicts the performance of TRevPAR between 2013 to 2015 .

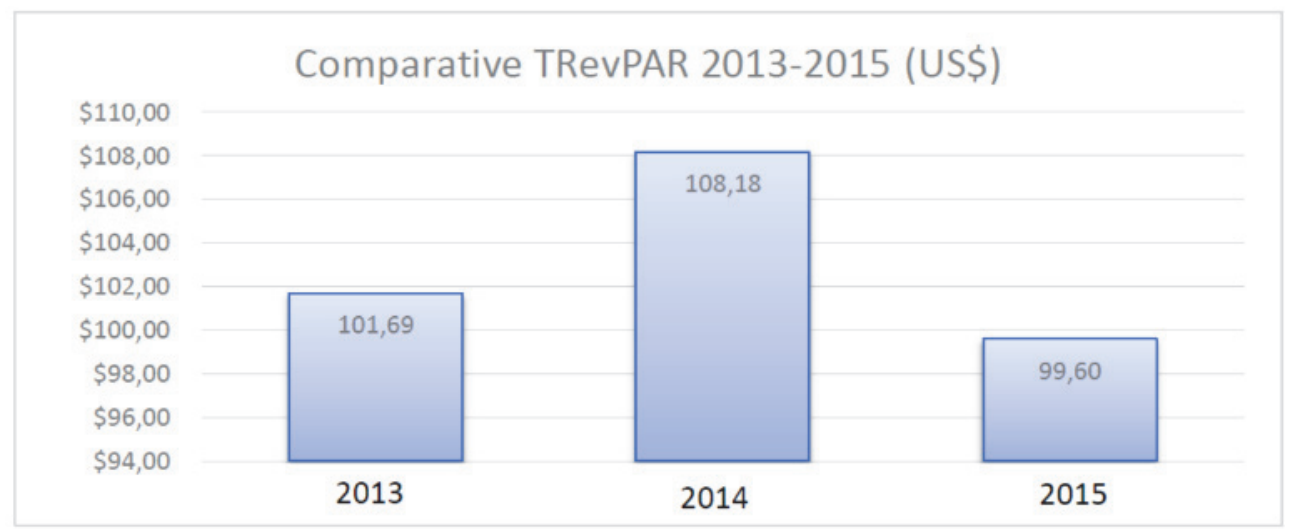

Figure 8. Annual TRevPAR between 2013 and 2015

Source: Prepared by the authors.

When analyzing the data collected by the prism of evolution of the monthly results, the following stand out:

i) In 2014, the good performance of the initial months motivated by the advance of corporate events;

ii) In 2014, the good performance of July / 14 which, although with low occupation, was sustained by the average revenue; 
iii) In 2014, the poor performance of the second half, in view of the economic slowdown, causing the resort search to fall in the corporate segment;

iv) In 2015, the weak performance of all segments throughout the year, with few improvements that could be highlighted, such as the July recovery;

Figure 9 shows the monthly performance of TRevPAR during the period of application of the research.

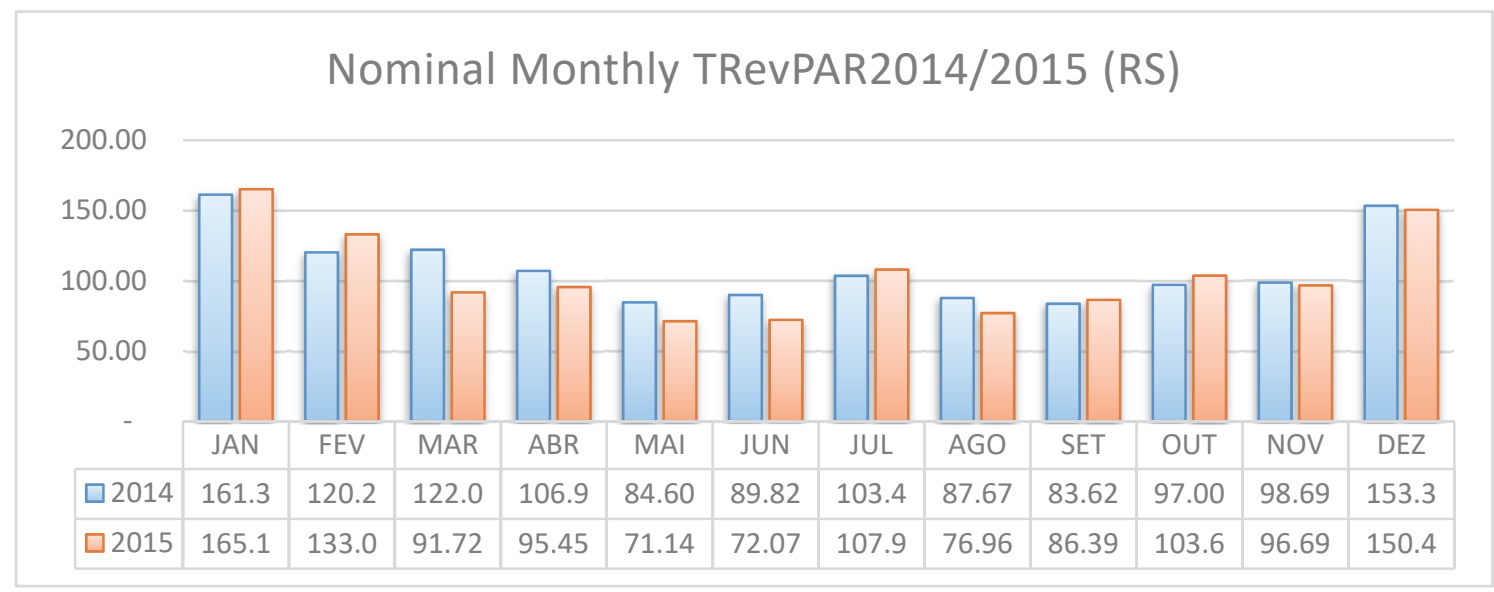

Figure 9. Monthly nominal TRevPAR between 2014 and 2015

Source: Prepared by the authors.

Regarding the variation in behavior, the figures confirm the above information in order to show the negative evolution of the variations occurring in the great majority of the months of 2015, with the exception of July / 15 , which registered a rise. Figure 10 shows this behavior.

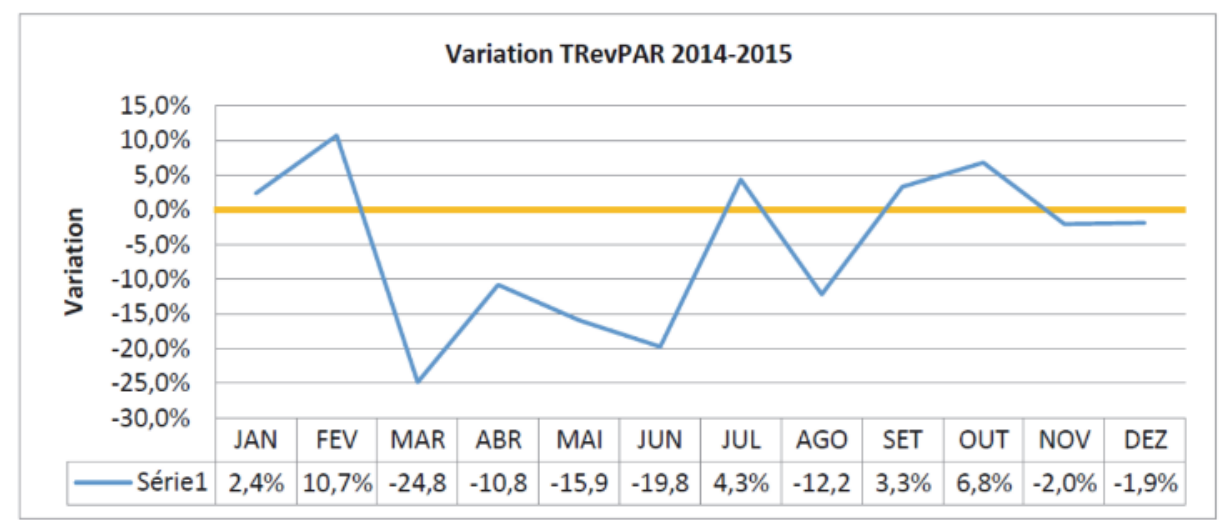

Figure 10. Monthly nominal TRevPAR variation between 2014 and 2015

Source: Prepared by the authors.

In a second moment the research sought to detail in a more specific way the performance of the enterprises, dividing them according to two logics: i) By geographical location: beach and countryside; ii) By type of pension practiced: all inclusive and others (Mid American Plan, Full American Plan and Bed \& Breakfest).

This action sought to highlight sales performance differentials according to the characteristics of each subgroup, as well as to seek to understand a pattern of behavior that characterizes each of these categories. Sections 4.2 and 4.3 will do these approaches

\subsection{Performance by Subgroups Geographic Location between Beach and Field}

When compared by location, the conclusion one arrives at is that the beach resorts oscillate more abruptly than the ones of the field. This evidence shows that the management of the resorts located in the beach environment tends to generate more uncertainties in the construction of future sales, requiring, from the managers, greater flexibility of actions. During the first months of the year, beach resorts tend to generate more revenue because 
leisure tourism is more intense. In the middle of the year, both are equivalent. Countryside resorts stand out in August. In the other months of the second half, with the exception of year-end, the contryside resorts tend to have higher sales volume, due to the greater participation of the corporate segment. In the end-of-the-year and early-holiday packages, beach resorts tend to present more significant values, due to the increased participation of leisure demand, presenting the best combination of occupancy and average income, leveraging the TRevPAR index. Regarding the analyzed period, it was verified that due to the dependence of corporate events on the part of the country resorts, and to the slowdown of the country's economy in 2015, this group suffered a more significant sales drop during the analyzed period. Figure 11 shows the oscillations in 2015. This picture reproduces the same behavior of the previous year.

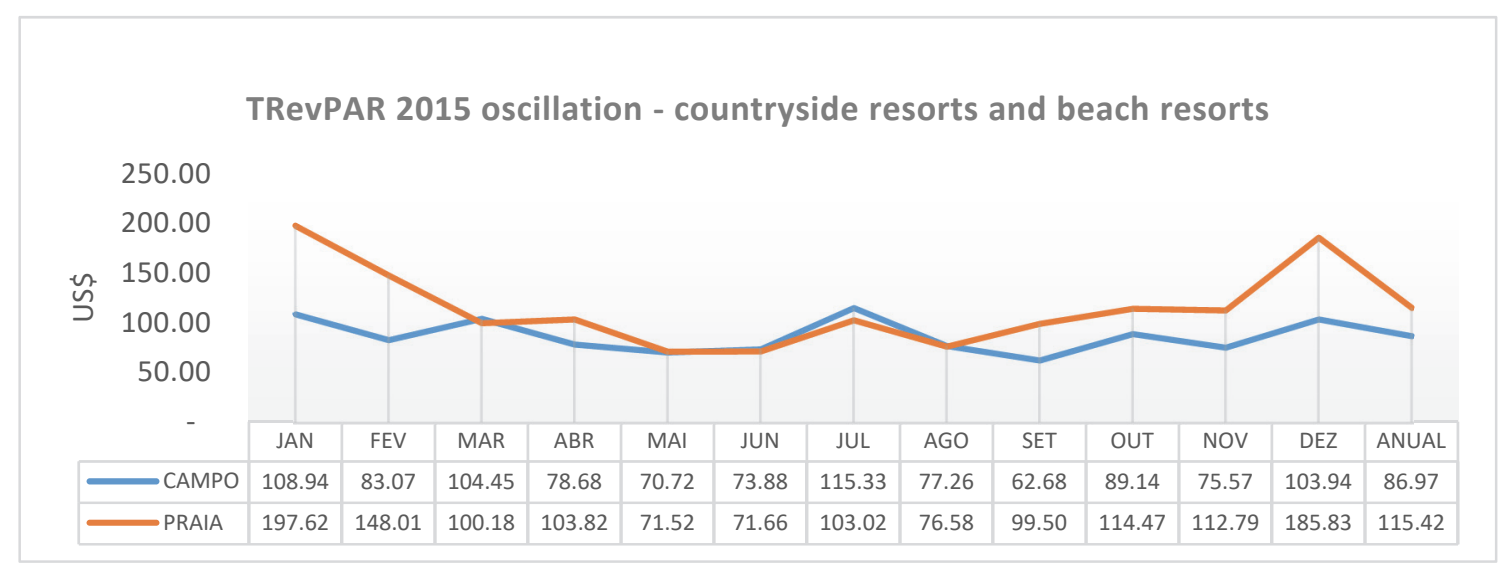

Figure 11. TRevPAR 2015 oscillation, beach resorts and beach resorts

Source: Prepared by the author

Thus, a tendency of seasonal behavior in each of these subgroups is evidenced. The measurement index adopted was the TRevPAR, in the sense of more accurately portraying the sales behavior of the studied segments.

\subsubsection{Geographical Location Considerations for Resorts}

The geographic location tends to generate a different behavior between the groups. The months of January, February and December, notably tend to generate superior performance at beach resorts. Another fact evidenced is that the subgroup of countryside resorts tends to present indexes that oscillate less aggressively than the beach resorts. The average variation between resorts located on the beach is higher and tends to behave more unpredictably. The amplitude between the high and low peaks of the beach resorts TRevPAR reached $63.8 \%$. The resorts located in the countryside had a range of variation, between high and low peaks, of $45.7 \%$. While on the one hand the smaller oscillation of the resorts located in the contryside allows to realize a more precise and assertive planning, the amplitudes more significant of the beach resorts allow a performance, in certain special dates, much more significant. In the end, the beach resorts generated a TRevPAR $32.7 \%$ higher than the countryside resorts.

\subsection{Performance by Subgroups by Type of Daily Rate: All Inclusive and Others}

The TRevPAR results of these two groups were put in analogy in order to also detect a trend of seasonal performance of sales effectiveness. The graphics were based on the year 2015, but, as in the classification by location, the seasonal behavior of the previous year was similar to that. In this subdivision, unlike the resorts segmented by location - the behavior during the months of the year was extremely egalitarian. The revenue's peaks highs and lows occurred in the same months, generating an extremely close TRevPAR in July. It should be emphasized that what is sought is not to verify which subgroup generates the highest revenues, but rather, how they behave during the year. Thus, it is noticeable that all-inclusive resorts generate a higher TRevPAR, as revenues from other departments are also accounted for, as opposed to resorts that operate other types of daily rate.

Figure 12 shows both the monthly seasonal behavior and the annual behavior for the two subgroups. 


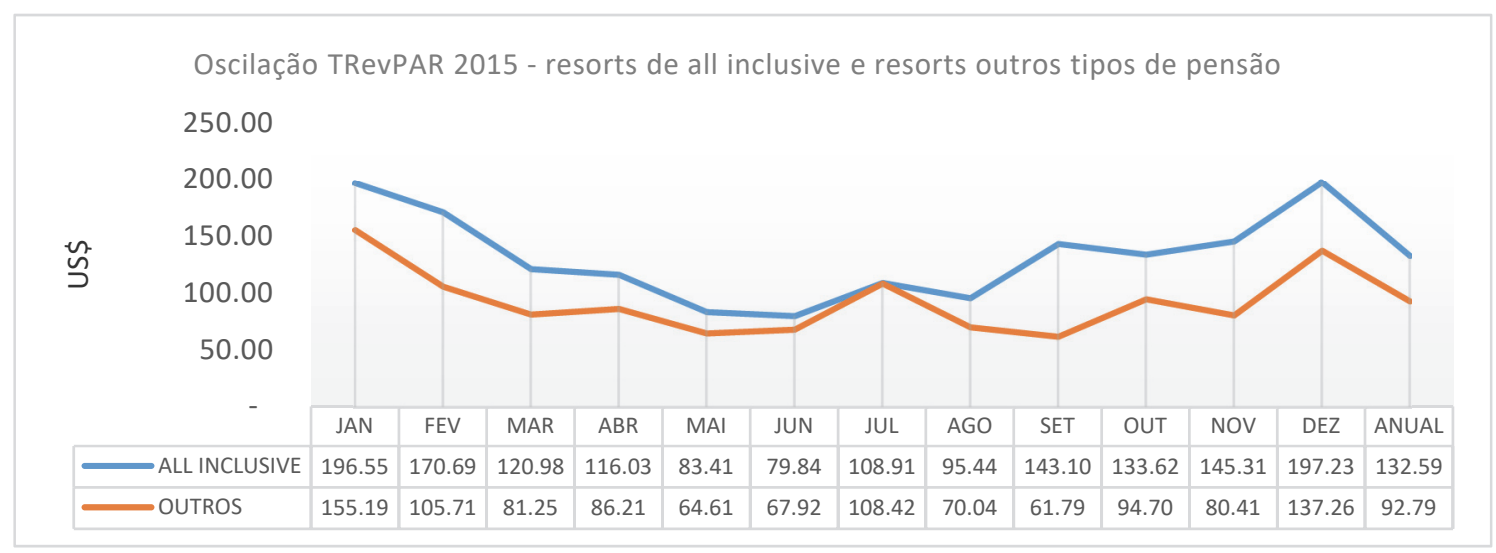

Figure 12. TRevPAR 2015 oscillation, all inclusive resorts and resorts other types of pension

Source: Prepared by the authors.

The range of variation of the high and low peaks of the two subgroups indicates the similar performance revenue behavior: Resorts operating in the all inclusive system had a range variation of $42.3 \%$, while the subgroup of other resorts operating other kinds of daily rates had a variation of $39.8 \%$.

\subsubsection{Considerations about the Resort'S Daily Rate}

When analyzing the performance of the two subgroups, based on the adopted daily rate, it is noticed that, unlike the division by location, the behavior tends to be close. In this sense, the type of daily rate operated by the resorts, although it causes oscillation, does not interfere in results as pronounced as location. In observing the behavioral lines, it was observed that, although they operate at different levels of unitary TRevPAR, such lines have a very similar monthly sequence.

\subsection{Final Considerations}

After analyzing the data of the Brazilian resorts during the years 2014 and 2015, it was verified that the macroeconomic factors exerted a strong influence on the general performance of the sector. All indices analyzed suffered oscillations, both upward and downward, caused by different behaviors of the Brazilian economy. With regard to the positive aspects, the mega-event FIFA 2014 World Cup helped the good performance in the first half of 2014. Two segments were highlighted:

i) The corporate events that, in Brazil, have a large participation in the Market mix of the resorts, generated positive values due to the advance of the events before the mega event and;

ii) The leisure segment was extremely benefited by the mega-event FIFA World Cup during that period of 2014, raising both the occupancy rate and the average revenue and, consequently, the resorts' TRevPAR, especially the high incidence of foreign tourists during the mega-event.

However, as of the second half of 2014, the strong economic oscillations were present and exerted an increasingly significant negative influence. Gradually, as the crisis worsened, demand surged more modestly in the resorts, especially the slowdown in the corporate event segment.

Initially the segment showed a sharp drop, with companies containing expenses abruptly. Then the leisure segment also showed a decline in performance, with families showing less confidence in the country's economy and failing to consume entertainment products. As a result, the outlook ended 2014 and entered 2015. Throughout this period, influenced by macroeconomic behavior, the resorts failed to show constant growth data, year by year, interrupting a process that began in 2009 .

The year 2015 was not positive for almost any sector of the Brazilian economy, and the period after the FIFA World Cup was not positive for the hotel industry as a whole. The resorts had to resort to spending cuts, and intensified sales campaigns to keep customers. Concerning the subgroups, all were influenced by the economic oscillations. In general, with regard to the type of pension practiced, it can be said that all-inclusive resorts were the least affected by the rise in the dollar's price, due to the fact that the Brazilian chose to move around the country, rather than traveling to overseas, due to the high cost of international packages. Likewise, as far as location is concerned, beach resorts were less affected by economic swings.

Thus, the economic slowdown and increased competition for stagnant demand triggered the appropriation of new 
management tools that focused on the reduction of expenses and, at the same time, the creation of products with greater added value. The policy of market expansion continues and has changed, focusing on the maintenance of customers, offering a product of better quality, without raising the final price. Therefore, the process of continuous improvement of the market performance of Brazilian resorts requires the in-depth analysis of the macro and micro-economic behavior aspects of the market, as well as the influence of these data on the sector as a whole. The analytical reports have become a reference base for short and medium term, by entrepreneurs of the enterprises. In this way it also allows managers to anticipate strategic decisions. It is also worth noting the importance of improving market observatory mechanisms, as in the case of the report of the Brazilian Association of Resorts, titled Resorts Brasil em Perspectiva, based on a simple basis of analysis of occupancy rate, average daily and general TRevPAR, for a more in-depth observation based on economic behavior and more accurate data generation of occupancy rate by segment, average revenue per segment and, consequently, TRevPAR by segment.

However, the present study also intends, in a second moment, to focus on the expenses generated in the operation of the various subgroups of resorts, detecting the differences in spending between such subclassifications. The cycle of studies intends, over time, to generate a calculation base that allows a greater effectiveness in the planning of the day-to-day management of the resorts.

\section{Acknowledgments}

We are thankfull for all teachers and people who provided knowledge to write this article, mainly Antonio Carlos Bonfato.

\section{References}

Agarwal, S. (2002). Restructuring seaside tourism: resorts life cycle. Annals of Tourism Research, 29(1), 25-55.

American Psychological Association. (1972). Ethical standards of psychologists. Washington, DC: American Psychological Association.

Associação Brasileira de Resorts. (2013). RBEP - Resorts Brasil em Perspectiva $\mathrm{n}^{\circ}$ 13. São Paulo: SENAC/Resorts Brasil.

Associação Brasileira de Resorts. (2014). RBEP - Resorts Brasil em Perspectiva $\mathrm{n}^{\circ}$ 14. São Paulo: SENAC/Resorts Brasil.

Associação Brasileira de Resorts. (2015). RBEP - Resorts Brasil em Perspectiva $\mathrm{n}^{\circ}$ 19. São Paulo: SE-NAC/Resorts Brasil.

Associação Brasileira de Resorts. (2016). RBEP - Resorts Brasil em Perspectiva $\mathrm{n}^{0}$ 23. São Paulo: SENAC/Resorts Brasil.

Associação Brasileira de Resorts. (2017a). RBEP - ABR em Números n ${ }^{\circ}$ 24. São Paulo: SE-NAC/Resorts Brasil.

Associação Brasileira de Resorts. (2017b). RBEP - ABR em Números $\mathrm{n}^{\circ}$ 25. São Paulo: SE-NAC/Resorts Brasil.

Associação Brasileira de Resorts. (2017c). RBEP - ABR em Números $\mathrm{n}^{\circ}$ 26. São Paulo: SENAC/Resorts Brasil.

Banco Central do Brasil (BCB) (2013). Atas do Comite de Política Monerária - COPOM $172^{a}$ a $179^{a}$ reunião. Brasília: BCB

Banco Central do Brasil (BCB) (2014). Atas do Comite de Política Monerária-COPOM $180^{a}$ a $187^{a}$ reunião. Brasília: BCB

Banco Central do Brasil (BCB) (2015). Atas do Comite de Política Monerária-COPOM $188^{a}$ a $195^{a}$ reunião. Brasília: BCB

Banco Central do Brasil (BCB) (2016). Atas do Comite de Política Monerária-COPOM 196 reunião. Brasília: BCB.

Boeger, M. A., \& Yamashita, A. P. (2005). Gestão financeira para meios de hospedagem. São Paulo: Atlas.

Bonfato. A. C. (2006). Desenvolvimento de Hotéis: estudo de viabilidade. São Paulo: SENAC.

Bonfato. A. C., \& Baltieri, M. A. T. (2016). Resorts no Brasil: uma avaliação do desempenho. Revista Brasileira de Pesquisa em Turismo. São Paulo, 10(2), 351-373, maio/ago.

BSH International. (2011). Relatório de Investimentos no Brasil: hotéis e resorts 2011, São Paulo:BSH.

BSH International. (2014). Resorts no Brasil: 2014. São Paulo: BSH.

Canteras Associados (2011). Hotel Invest: relatório aos investidores hoteleiros. São Paulo:HVS. 
Costa, S. F. Método científico: os caminhos da investigação. São Paulo: Harbra, 2001. 372

Dencker, A. F. M., \& Bueno, M. (orgs.) (2003). Hospitalidade: cenários e oportunidades. São Paulo: Pioneira Thomson Learning.

Domingues. R. (entrevista pessoal na sede da Associação Brasileira de Resorts, 11 de novembro, 2014).

Gee, C. Y. (1998). Resorts development and management. 2. ed. East Lansing, Mich.: Educational Institute of the American Hotel \& Motel Association - AMHA.

Gil, A. C. (1997). Metodologia do ensino superior. 3. ed. São Paulo: Atlas.

Gil, A. C. (2008). Como elaborar projetos de pesquisa. 4. ed. São Paulo: Atlas.

Globo, O. (2016). Setor de serviços acumula queda de 3,6\% em 2015, a maior da história. Acesso em 14 de março de Retrieved from http://g1.globo.com/economia/noticia/2016/02/volume-do-setor-de-servicos-registra-queda-de-36-em-2015diz-ibge.html

Goeldner, C. R., Ritchie, J. R., \& Mcintosh, R. W. (2002). Turismo princípios, práticas e filosofias. 8. ed. Porto Alegre: Bookman.

Guijarro, D. (2003). Guia de resorts brasileiros. São Paulo: Online editora.

JLL Jones Lang LaSalle. (2014). Resorts em números 2013. São Paulo: Jones Lang LaSalle - JLL

JLL Jones Lang LaSalle. (2015). Hotelaria em números 2014. São Paulo: Jones Lang LaSalle - JLL

Laukatos, E., \& Marconi, M. A. (2001). Fundamentos da metodologia científica. 4. Ed. São Paulo: Atlas.

Mill, R. C., \& Kahl, S. (2003). Resorts: administração e operação. São Paulo: Bookman.

Ministério do Turismo (MTUR) (2014). Turista de negócios gasta quatro vezes mais que o de lazer. Acesso em 18 de março de 2015.2 Retrieved from http://www.brasil.gov.br/turismo/2014/09/turista-de-negocios-gasta-quatro-vezes-mais-que-o-de-lazer

Panrotas. (2015). Faturamento de agências Abracorp cai 2,3\% em. Acesso em 16 de março de 2016. Retrieved from

http://www.panrotas.com.br/noticia-turismo/viagens-corporativas/2016/01/faturamento-de-agencias-abracor p-cai-23-em-2015_123018.html

Papatheodorou, A. (2004). Exploring the evolution of tourism resorts. Annals of Tourism Research, 31(1), 219-237.

Prosérpio. R. (2007). O avanço das redes hoteleiras Internacionais no Brasil. Sao Paulo: Aleph, 2007.

Pullman, M., \& Thompson G. M. (2002). Evaluating capacity- and demand-management decisions at a ski resort. Cornell Hotel and Restaurant Administration Quarterly, 43(6), 25-36

Rosa, S. E. S., \& Tavares, M. M. (2012). A recente expansão dos resorts no Brasil. BNDES Setorial, Rio de Janeiro, n. 16, set. 2012. Acesso: 12/08/2012. Retrieved from www.bndes.gov.br/SiteBNDES/bndes/bndes_pt/Institucional/Publicacoes/Consulta_Expressa/Setor/Turism o/200209_16.html

Santella, L. (2006). Comunicação e pesquisa: projetos para mestrado e doutorado. 2. ed. São Paulo: Hacker.

Valor Econômico. (2016).Vendas em turismo de negócios recuam 3,6\% em 2015 no país, diz Alagev. Acesso em 14 de abril de $\quad$ Retrieved from http://www.valor.com.br/empresas/4436592/vendas-em-turismo-de-negocios-recuam-36-em-2015-no-pais-d iz-alagev

\section{Copyrights}

Copyright for this article is retained by the author(s), with first publication rights granted to the journal.

This is an open-access article distributed under the terms and conditions of the Creative Commons Attribution license (http://creativecommons.org/licenses/by/4.0/). 